\title{
Must deacidification with an induced flocculant yeast strain of Schizosaccharomyces pombe
}

\author{
Maria João Sousa ${ }^{1}$, José António Teixeira ${ }^{1}$, Manuel Mota ${ }^{2}$ \\ ${ }^{1}$ Center of Chemical Engineering, University of Porto, 4099 Porto Codex, Portugal \\ ${ }^{2}$ Department of Engineering Sciences-Biological Engineering, University of Minho, 4719 Braga Codex, Portugal
}

Received: 22 May 1992/Accepted: 25 September 1992

\begin{abstract}
The use of flocculant cells of the yeast strain Schizosaccharomyces pombe for the deacidification of grape musts in continuous culture was developed. An external loop reactor was used to induce flocculation. The flocs obtained were stable in the $\mathrm{pH}$ range 3.0-6.0 and in the presence of several sugars. Some inhibition was observed for high (above 6.0) and low (below 3.0) $\mathrm{pH}$ values. Once induced, flocculation could no longer be completely inhibited. Vinho Verde, a typical Portuguese wine, has a relatively low ethanol content and a high acid concentration. The external loop reactor loaded with the flocculant cells was used to deacidify a synthetic medium with sugar and malic acid concentrations similar to the ones found in Vinho Verde grape must. A desirable malic acid decrease with moderate glucose consumption was obtained at a dilution rate of $0.7 \mathrm{~h}^{-1}$. Improved results were obtained when the synthetic medium was replaced by Vinho Verde grape must.
\end{abstract}

\section{Introduction}

Vinho Verde wines are typical Portuguese wines characterized by a relatively low alcohol content and a high malic acid concentration (varying from 6 to $12 \mathrm{~g} / 1$ ). A partial reduction in the malic acid content, viz. to $4 \mathrm{~g} / \mathrm{l}$, is considered beneficial, as it decreases the acidity of the wine, preserving at the same time its typical flavour and taste.

The use of the yeast Schizosaccharomyces pombe for deacidification of high acidity grape musts has been studied by several researchers. Pure or mixed fermentations with Saccharomyces cerevisiae have been proposed (Ethiraj et al. 1983; Yang 1973). Sequential fermentation using initially Schizosaccharomyces pombe followed by Saccharomyces cerevisiae have also been studied (Ethiraj et al. 1983; Gallander 1977). Better results

Correspondence to: M. Mota were obtained when Schizosaccharomyces pombe cells were removed before inoculation with Saccharomyces cerevisiae (Snow and Gallander 1979). However, most proposed processes have been of the batch type. Magyar and Panyk (1989) proposed the utilization of Ca-alginate entrapped cells both in batch and continuous culture. Ca-alginate was not, however, a good entrapment agent for the deacidification of musts, since the high sugar concentration led to cell growth with consequent gel destruction. The aforementioned authors proposed that the deacidification should be done on the wine rather than on the must. However, the ethanol concentrations present in the wine greatly reduce both malic acid degradation and cell viability, making the deacidification process difficult to control (Sousa et al. 1991).

Continuous culture is more productive than batch growth (Pirt 1985), especially when a high-density cell culture is used (Mehaia and Cheryan 1984; Mota et al. 1987). One of the simplest ways of obtaining high-density cell cultures is through the use of flocculant cells. Flocculation enables high cell densities to be obtained in a continuous bioreactor without the use of any inert carrier or entrapment agent, taking advantage of the natural sedimentation capacity of the cells. It is therefore a low-cost process. Furthermore, no strange substances, which could alter the product, are introduced into the system, and no drastic conditions must be applied for immobilization of the cells. These features can be effectively used in food processing.

The induction of flocculation ability in a strain of Schizosaccharomyces pombe, using the medium of Hsiao et al. (1983) and an external loop reactor is described in this work (Mota and Teixeira 1990). The performance of the bioreactor in the deacidification of a synthetic medium or grape must was studied.

\section{Materials and methods}

Yeast strain. S. pombe SG2 was isolated by the Institut Coopératif du Vin of Montpellier and was kindly provided by Prof. Pierre Strehaiano (IGC, Toulouse, France). 


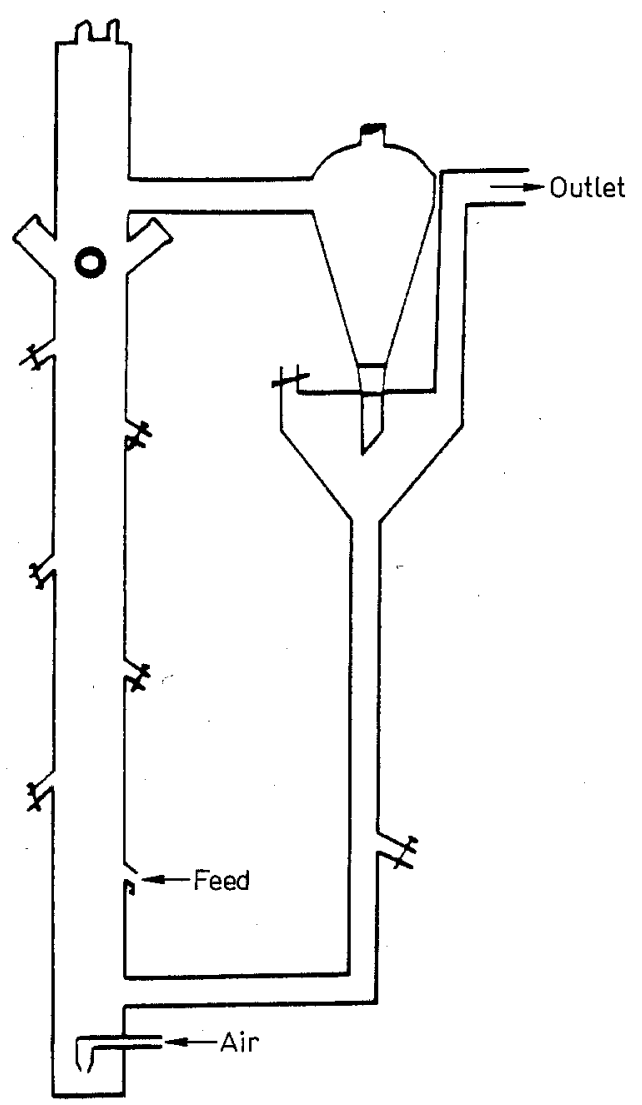

Fig. 1. Schematic representation of the external loop reactor

Induction of flocculation in batch culture. The procedure described by Hsiao et al. (1983) was adopted to attempt the induction of flocculation in batch culture.

Induction of flocculation in continuous culture. S. pombe cells were pre-cultured for $48 \mathrm{~h}$ in an erlenmeyer flask, and then transferred to an external loop reactor (Fig. 1). The medium used for the inoculum and for continuous culture, contained in tap water: $3 \mathrm{~g}^{-1}$ of malt extract, $3 \mathrm{~g}^{-1}$ of yeast extract, $5 \mathrm{~g}^{-1}$ of Bactopeptone and $50 \mathrm{~g} \mathrm{l}^{-1}$ of glucose. For the continuous culture, medium was fed to the reactor at a dilution rate of $0.1 \mathrm{~h}^{-1}$. The dilution rate was calculated as the volume of medium fed to the reactor per hour per volume of the reactor. Temperature was kept at $30^{\circ} \mathrm{C}$, and aeration at $0.09 \mathrm{vvm}$ (volume of air per volume of fermentor per minute; $\left.11^{-1} \min ^{-1}\right)$.

Measurement of flocculation ability. The flocculation ability of the induced strain was assayed using a modification of the Helm sedimentation test (Stewart 1975). After being washed three times with ultrapure water, cells were suspended in a $4 \mathrm{mM} \mathrm{CaCl}_{2}$ solution adjusted to $\mathrm{pH} 4.0$ with $\mathrm{HCl}$. The suspension was then placed in a $25-\mathrm{ml}$ cylinder and inverted four times for homogenization. At defined intervals, samples were taken from a fixed position (level corresponding to $20 \mathrm{ml}$ ), and the biomass concentration was measured spectrophotometrically at $620 \mathrm{~nm}$. From the biomass concentrations obtained the proportion of cells (in \%) remaining in suspension at each defined time was calculated and the sedimentation profile was plotted. The $\mathrm{pH}$ values were recorded at the beginning and at the end of the sedimentation test. The $\mathrm{pH}$ variation was never higher than 0.2 . For the $\mathrm{pH}$ studies the $4 \mathrm{mM} \mathrm{CaCl} \mathrm{m}_{2}$ solution was replaced by buffer solutions containing $4 \mathrm{mM} \mathrm{CaCl}_{2}$ : $\mathrm{pH} 2.2$ and 3.0, glycine/ $\mathrm{HCl}$ buffer; $\mathrm{pH} 4.0$ and 6.0, succinic acid/NaOH buffer: pH 8.0, TRIS/HCl buffer.
Deacidification assays. These studies were done in the reactor described above. The medium used for the assays contained in tap water: $4 \mathrm{~g}^{-1}$ of yeast extract, $5 \mathrm{~g} \mathrm{l}^{-1}$ of $\mathrm{KH}_{2} \mathrm{PO}_{4}, 0.4 \mathrm{~g} \mathrm{l}^{-1}$ of $\mathrm{MgSO}_{4} \cdot 7 \mathrm{H}_{2} \mathrm{O}, 130 \mathrm{~g} \mathrm{l}^{-1}$ of glucose and $9 \mathrm{~g} \mathrm{l}^{-1}$ of $\mathrm{L}(-)$ malic acid. Five dilution rates were studied: $0.1,0.26,0.5,0.7$ and $1.0 \mathrm{~h}^{-1}$ The temperature was kept at $30^{\circ} \mathrm{C}$ and the aeration rate at $0.005 \mathrm{vvm}$. An assay using Vinho Verde grape must was also performed, at a dilution rate of $0.7 \mathrm{~h}^{-1}$. The reducing sugar concentration in the must was $140 \mathrm{~g} \mathrm{I}^{-1}$, and the $\mathrm{L}(-)$ malic acid concentration was $8.5 \mathrm{~g} \mathrm{l}^{-1}$.

Sample analysis. The biomass dry weight was determined by filtering $10 \mathrm{ml}$ of sample through a $0.45-\mu \mathrm{m}$ Millipore membrane and drying it at $100^{\circ} \mathrm{C}$ until constant weight. Glucose concentrations were determined by the 3,5-dinitrosalicylic acid method (Chaplin 1986). Malic acid concentration was determined by an enzymatic assay using malate dehydrogenase (Amerine and Ough 1974). Ethanol concentration was determined by gas chromatography (model 5894 Hewlett Packard with a flame ionization detector) using isopropanol as internal standard.

\section{Results and discussion}

\section{Induction of flocculation}

Unlike the case described by Hsiao et al. (1983) flocculation could not be induced in a batch culture for the strain used in this work. The aggregates obtained by this process were only visible microscopically, and they were not able to settle down in the growth medium. Also Helm's sedimentation test was negative (Fig. 2). However, when cells were cultivated in an external loop reactor flocs became rapidly visible. Twenty-four hours after the start of the continuous culture, most of the cells were already clumped in aggregates that could be seen macroscopically. The aggregate size kept on increasing and by the fifth day the big flocs that had been formed showed a high sedimentation rate (Fig. 2). The floc size stabilized thereafter. The biomass concentration in the reactor increased from 2.0 to $39 \mathrm{~g} / 1$ between the second and fifth days.

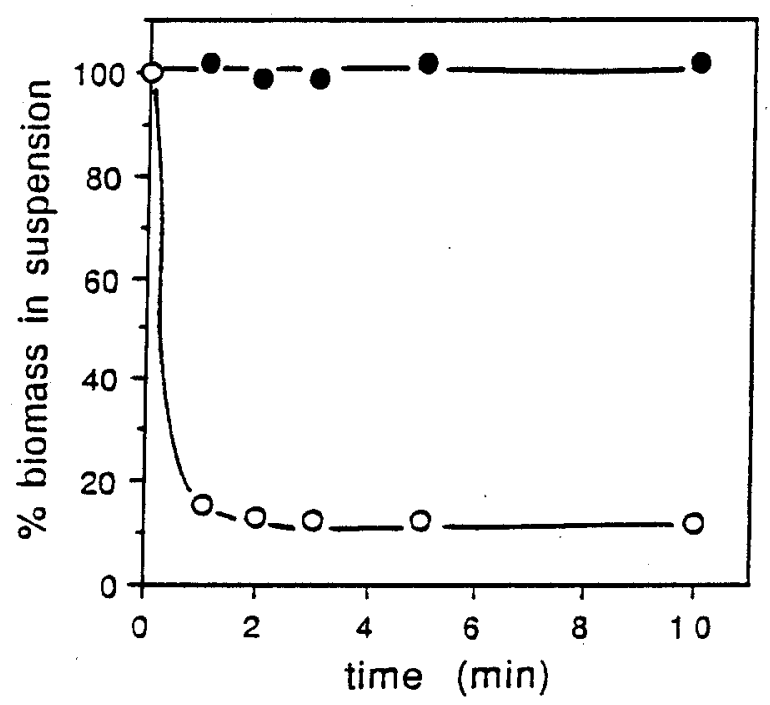

Fig. 2. Sedimentation profiles of cells grown in batch (๑) and continuous culture $(\mathrm{O})$ 


\section{Stability and inhibition of flocculation}

To investigate the stability of the flocs, we did some sedimentation tests under various conditions. The influence of $\mathrm{pH}, \mathrm{L}(-)$ malic acid $(5 \mathrm{~g} / 1)$ and several sugars $(50 \mathrm{~g} / \mathrm{l})$ were studied. Figure 3 represents the fraction of settled cells after $10 \mathrm{~min}$ sedimentation at different $\mathrm{pH}$ values. Flocculation was not significantly affected in the $\mathrm{pH}$ range 3.0-6.0. At $\mathrm{pH}$ values out of that range the flocculation was affected; a decrease in the settling rate was observed, which was more pronounced for low than for high values of $\mathrm{pH}$. However, even for $\mathrm{pH} 2.2$, more than $50 \%$ of the cells had settled down in $10 \mathrm{~min}$. Sedimentation tests in the presence of glucose, galactose, fructose, mannose and L(-)malic acid were also performed. Fructose, mannose and $\mathrm{L}(-)$ malic acid did not

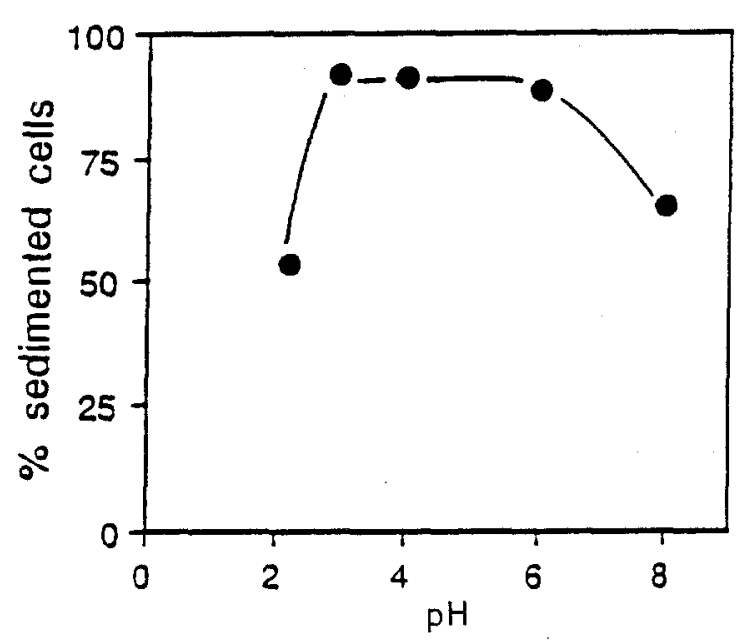

Fig. 3. Percentage of sedimented cells after a 10-min settling period in sedimentation tests at different $\mathrm{pH}$ values

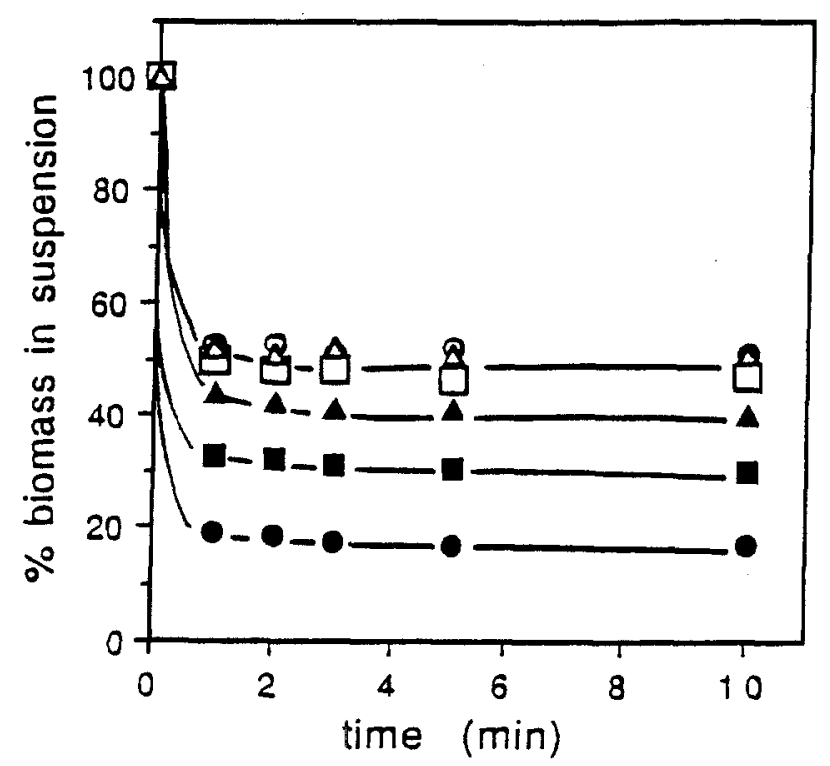

Fig. 4. Sedimentation profiles of cells grown in continuous culture in the presence of: $O$, water (control); $\square$, glucose, $50 \mathrm{~g}^{-1} ; \Delta$, galactose, $50 \mathrm{~g} \mathrm{l}^{-1} ; \mathrm{Ca}^{2+}, 4 \mathrm{~mm} ; \mathrm{C}$, glucose, $50 \mathrm{~g}^{-1}$ plus $\mathrm{Ca}^{2+}$, $4 \mathrm{mM} ; \Delta$, galactose, $50 \mathrm{~g} \mathrm{l}^{-1}$ plus $\mathrm{Ca}^{2+}, 4 \mathrm{mM}$ affect flocculation. Galactose inhibited the calcium-promoted flocculation. Glucose had a similar but less pronounced effect than galactose (Fig. 4). Total inhibition of flocculation was never observed, even under such drastic conditions as $15 \mathrm{~g} / 1$ of $\mathrm{NaCl}, \mathrm{pH} 2.0$ or $200 \mathrm{mM}$ ethylenediaminetetraacetate (EDTA).

\section{Identification of flocculation type}

Johnson et al. (1988) established an experimental procedure to distinguish sexual from asexual flocculation. According to these authors the asexual flocculation of $S$. pombe cells is mediated by calcium ions and inhibited by $50 \%(\mathrm{w} / \mathrm{v})$ galactose and by $10 \mathrm{~mm}$ EDTA. On the other hand, sexual flocculation is independent of $\mathrm{Ca}^{2+}$ ions and is not inhibited by the former substances. As our strain is homothallic, both hypotheses could be considered. The application of the foregoing criterion was unfortunately not conclusive. Indeed, although flocs remained in the presence of $50 \%(\mathrm{w} / \mathrm{v})$ galactose or $10 \mathrm{~mm}$ EDTA, suggesting sexual flocculation, an increase in flocculation was also obtained in the presence of calcium, showing some dependence on this ion.

\section{Deacidification}

After the induction of stable flocs, a medium containing $9 \mathrm{~g} \mathrm{l}^{-1}$ of $\mathrm{L}(-)$ malic acid and $130 \mathrm{~g} \mathrm{l}^{-1}$ of glucose was fed to the reactor. In order to find the dilution rate that would give the desired malic acid decrease with minimum glucose consumption, five different dilution rates were tested starting with the lowest value $\left(0.1 \mathrm{~h}^{-1}\right)$. After a stationary period, during which samples were collected and analysed, the dilution rate was increased to the next chosen value. Reduced glucose consumption is desirable since the ethanol yields found with this yeast strain are lower than those reported for Saccharomyces cerevisiae (Dittrich 1963). Furthermore, a high glucose consumption would compromise the traditional ethanol fermentation subsequent to deacidification. Data in Table 1 represent the average values obtained for each dilution rate. Deacidification was almost complete for the lower dilution rates $\left(0.1,0.26\right.$ and $\left.0.5 \mathrm{~h}^{-1}\right)$ but glucose consumption was too high. At a dilution rate of $0.7 \mathrm{~h}^{-1}$, a desirable malic acid depletion was obtained with moderate glucose consumption.

As shown in Fig. 5 the final glucose concentration increased linearly with the dilution rate. For a dilution rate of $1.0 \mathrm{~h}^{-1}$ wash-out was observed. The dilution rate had no significant effect on the ethanol yield. Since this yield is strongly dependent on the aeration rate (Sousa et al. 1991), a very low aeration rate was used $(0.005 \mathrm{vvm})$. The yield thus obtained was very close to the highest yield found in a batch culture with the same medium. In the stationary phase the dilution rate had also no significant effect on the cell retention capacity of the reactor (expressed as the ratio of biomass concentration in the reactor to biomass concentration in the effluent). This value remained almost constant (approxi- 
Table 1. Stationary state values obtained for different dilution rates

\begin{tabular}{|c|c|c|c|c|c|c|c|}
\hline $\begin{array}{l}\text { Dilution } \\
\text { rate } \\
\left(\mathrm{h}^{-1}\right)\end{array}$ & Medium & $\begin{array}{l}\text { Biomass }^{a} \\
(\mathrm{~g} / \mathrm{l})\end{array}$ & $\begin{array}{l}\text { Reducing } \\
\text { sugars } \\
(\mathrm{g} / \mathrm{l})\end{array}$ & $\begin{array}{l}\text { Malic } \\
\text { acid } \\
(\mathrm{g} / \mathrm{l})\end{array}$ & $\begin{array}{l}\text { Ethanol } \\
(\mathrm{g} / \mathrm{l})\end{array}$ & $\begin{array}{l}\text { Biomass } \\
\text { effluent }^{\mathrm{b}} \\
(\mathrm{g} / \mathrm{l})\end{array}$ & $\begin{array}{l}Y_{E} \\
(\%)\end{array}$ \\
\hline 0.26 & Synthetic & 34.6 & 31 & 0.14 & 43 & 2.1 & 43.4 \\
\hline 0.5 & Synthetic & 17.1 & 66 & 0.64 & 28 & 1.1 & 43.8 \\
\hline 0.7 & Synthetic & 12.3 & 102 & 2.4 & 12.3 & 0.9 & 43.9 \\
\hline
\end{tabular}

$\mathrm{Y}_{\mathrm{E}}$, mass of ethanol produced per mass of glucose consumed $\times 100$ $\left(\mathrm{g} \mathrm{g}^{-1}\right)$

a Biomass dry weight in the reactor

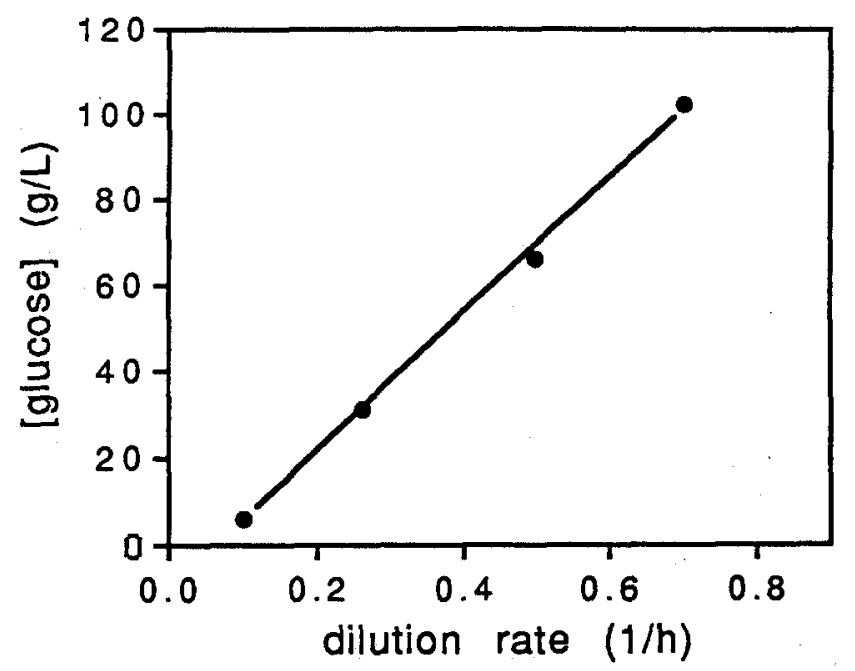

Fig. 5. Glucose concentration in the reactor at different dilution rates

mately 16) for the lowest dilution rates, decreasing slightly (to 14) for the highest dilution rate $0.7 \mathrm{~h}^{-1}$.

An assay performed with Vinho Verde must both confirmed and improved the results previously obtained with synthetic medium:

1. The malic acid conversion and sugar consumption observed were the same as before.

2. Slightly better results were obtained for the ethanol yield.

3. The cell concentration in the effluent decreased significantly.

With grape must, bigger flocs were obtained than when synthetic medium was used, which favoured cell retention in the reactor (cell retention capacity increased to 75). This accomplishment represents two additional advantages. On the one hand, less cells are released to the medium, thereby preventing a further proliferation of Schizosaccharomyces pombe during the ethanol fermentation stage. On the other hand, as cells are retained in the reactor the overall productivity increases.

Previously we concluded that a deacidification process with $S$. pombe should be conducted in must, before the implementation of traditional alcoholic fermentation (Sousa et al. 1991). In this work we have been suc-
${ }^{b}$ Biomass dry weight in the effluent

${ }^{c}$ Wash-out conditions

cessful in inducing the appearance of stable flocs of this yeast, having used them in a continuous deacidification process of synthetic medium. Good malic acid reduction with moderate glucose consumption can be obtained in this way. This system proved to give even better results when working with grape must. The must had an instantaneous effect on the flocculation efficiency of the cells. Cells flocculated better probably due to one of the following reasons: either the high ionic strength of the synthetic medium inhibited flocculation, or unidentified components present in the must favoured flocculation.

Since the final malic acid content in the treated must was too low, two alternative procedures may be chosen to control the final malic acid content of the wine: (a) taking advantage of the better stability of the flocs, higher dilution rates can be used, thereby increasing the productivity; (b) keeping $0.7 \mathrm{~h}^{-1}$ as the dilution rate, the treated malate-depleted must could be blended with untreated must, thereby reducing the total amount of must to be processed.

Acknowledgements. The authors thank NATO, which, through the programme NATO SFS PO-PORTOFOOD, provided the funding for this work. The author M. J. Sousa has a grant from JNICT (Junta Nacional de Investigação Científica).

\section{References}

Amerine MA, Ough CS (1974) Wine and must analysis. Wiley, New York

Chaplin MF (1986) Monosaccharides. In: Chaplin MF, Kennedy JF (eds) Carbohydrate analysis - a practical approach. IRL Press, Washington, D.C., pp 1-36

Dittrich HH (1963) Tests regarding the decomposition of malic acid by a yeast of the strain Schizosaccharomyces. Wein Wissen 18:392-405

Ethiraj S, Suresh ER, Onkarayya H (1983) Controlled deacidification of Bangalore Blue grape musts with Schizosaccharomyces pombe. J Food Sc Technol 20:248-250

Gallander JF (1977) Deacidification of Eastern table wines with Schizosaccharomyces pombe. Am J Enol Vitic 28:65-68

Hsiao H-Y, Chiang LC, Yang C-M, Chen L-F, Tsao GT (1983) Preparation and performance of immobilized yeast cells in columns containing no inert carrier. Biotechnol Bioeng 25:363375

Johnson BF, Walker T, Calleja GB, Seligy VL (1988) Sexual co- 
flocculation and asexual self-flocculation in budding and fission-yeast: experimental establishment of a fundamental difference. Can J Microbiol 34:1105-1107

Magyar I, Panyk I (1989) Biological deacidification of wine with Schizosaccharomyces pombe entrapped in Ca-alginate gel. Am J Enol Vitic 40:233-240

Mehaia MA, Cheryan M (1984) Hollow fibre bioreactor for ethanol production: application for the conversion of lactose by Kluyveromyces fragilis. Enzyme Microb Technol 6:117-120

Mota M, Teixeira JA (1990) Utilization of an external loop bioreactor for the isolation of a flocculation struin of Kluyveromyces marxianus. Curr Microbiol 20:209-214

Mota M, Lafforgue C, Strehaiano P, Goma G (1987) Fermenta- tion coupled with microfiltration: kinetics of ethanol fermentation with cell recycle. Bioprocess Eng 2:65-68

Pirt SJ (1985) Principles of microbe and cell cultivation. Blackwell, Oxford

Snow PG, Gallander JF (1979) Deacidification of white table wines through partial fermentation with Schizosaccharomyces pombe. Am J Enol Vitic 30:45-48

Sousa MJ, Teixeira JA, Mota M (1991) Malo-alcoholic fermentation: the influence of operating conditions on the kinetics of deacidificaton. J Wine Res $2: 115-124$

Stewart GG (1975) Yeast flocculation. Practical implications and experimental findings. Brew Dig 5:42-62

Yang HY (1973) Deacidification of grape musts with Schizosaccharomyces pombe. Am J Enol Vitic 24:1-4 